\title{
Wetting Risk Premiums in EPC Bid Value Using Monte Carlo Simulation
}

DOI 10.5592/otmcj.2011.1.2

Research paper

\author{
Pramendra Srivastava \\ (B. Tech Chemical, PGDM-Strategic Investments) \\ (Oil \& Gas field Development and Feasibility consultant) \\ E-mail: pramendrasri@gmail.com
}

ePC Project conceals challenges for Proposal Mangers to SPECULATE THE POSSIBLE RISKS AT THE TIME OF BIDDING. It is further challenge for project managers to keep the project activities in control within the limits set during bid process, without allowing any risk factor to creep in. The challenges lie in identifying the risks, breaking down risks to enable measurement and controls, estimating realistic and probabilistic risk premiums to be wetted into bid value. This paper expounds a simple and generic ways to characterize EPC project risks into measurable entities and evaluates risk impacts on costs and schedule using stochastic process of running Monte Carlo simulations integrated with Markov dependency. Here is a step by step approach in identifying the tangible, intangible and macro level risk factors; evaluates their risk premiums, rank and prioritize them; thus precipitating several decision points for optimal risk cover strategies aligning with project execution philosophies.

Keywords
EPC Risk Management,
EPC Risk
characterization, EPC
Bidding Strategies,
Wetting Risk Premium,
Probabilistic Risk
Estimation, Monte Carlo
Simulations, Bidding.

\section{INTRODUCTION}

The strength of an EPC bid lies, primarily in competitive strategies and secondly in competitive estimates, which may or may not consider all risks associated to execution strategies. A robust bid would probabilistically estimate risks premiums associated to project execution strategies and consider in the bid costs, schedule and Project Value, thus resulting into robust project execution as project can absorb uncertainties. Depending on the complexities and size of EPC project, Bid level business risk evaluation may consider the range of stochastic variations on key business drivers and cost determinants, which may further be refined after Project award and during execution. Higher the amount of investment, higher the economic risks and therefore higher the quality of analysis required. As EPC costs determinants and schedules precipitate, risk analysis infuses maximum and minimum limits on key project activities. Note that these are the probable range of variation and not the conditioned maxima and minima's, hence the need for dynamic analysis to generate a balanced and probabilistic estimate of overall cost and schedule 
impacts. Risk analysis embedded into bid stage itself reduces the volatility of the estimated profits and keeps Projects on track and closer to the planned reference scale. The clear benefit is an assurance of business quality and healthy Project execution and growth in market volumes over a long run. Failing which uncertainty rules and the project may dwindle out of control leading to not only financial losses but also loss of client credibility. However, care must be taken to avoid over estimation of Risks and going out of competition due to over quote. Hence, it is strongly advised to cautiously and judiciously strategize the risk levels and accordingly select the right decision point on EPC risk premiums depending on size, type and execution confidence of project teams.

There have been several approaches suggested by earlier researchers (Asbjørn Rolstadås, Agnar Johansen, 2008 and S.M. Seyedhoseini1 and M.A. Hatefi, December 2009). However, this paper takes a new approach in defining, characterizing and measuring the risk, keeping the Bidding strategy in focus. The paper would meet the following challenges in a step by step approach establishing a simple and formidable EPC projects risk estimation technique. At the end of paper, Bid managers would have a choice to select several decision points to add risk premiums, depending on the type, size, and their confidence in project execution. These are:

1. Define and characterize risks

2. Identify \& Measure Tangible Risks

3. EPC Risk-break down using project activities - micron zing the risk elements.

4. Develop the base model to measure impact of tangible risks

5. Identify \& Measure Intangible Risk,

6. Characterization to convert Intangibles into measurable categories - create Markov chains
7. Develop base model for determination of Intangible Risks.

8. Macro risk wetting

9. Analyze Sensitivities and Rank them.

10. Summarize, analyze and discuss the strategic decision points

\section{Define risks}

ePC value chain comprises a number of steps involving hundreds of contractors, and sub contractors, and a team of thousands individuals (Madhu Pillai, Dr Eric Sandelands, Ganesh Ashokan, 2010 and Paté-Cornell, M. E., and Regan, P.J., 1998). The errors can prop at any stage; conceptualization, bidding, planning, Engineering, procurements, construction, execution, transportation, Installation and commissioning and handover. An Experts Survey with highly experienced EPC professionals, having an average experience of more than 20 years was performed. They were questioned about what the top twenty biggest risks in EPC projects are and to rank them. Respondents, mostly from oil \& gas sector replied 'unpredictable' and immeasurable' reasons falling in intangible categories and of-course with different perspective of importance, impacts and ranking. Following are some of the factors that emerged from expert's survey:

1. Schedule delayed-Mile stone payment delayed

2. Bid price Escalation \& validity expired: Bid supporting vendor's priced one year back, $10 \%$ inflation on local costs and $5 \%$ escalation international markets, and $5 \%$ in foreign exchange pricing expected.

3. Construction issues that were not anticipated during bid: like need for additional hire of contractors / personnel, delay in inspection and arrival of long lead items with custom clearance,

4. Repeated work due to improper quality,
5. Market Boom, Demands exceed supply. Contractor's Rates exploded by $10-30 \%$ up.

6. Manpower crisis, high attrition in the market, increase in salary up by $50 \%$, resignation of contractor's key skilled workers and non availability of equivalent skills)

7. Non availability of construction machineries (cranes), for 3-6-12 months. - delays

8. Non availability of raw materials(steel etc), consumables, chemicals and spares for 1-2-3 months.- delays

9. Liquidated Damages - insured risks not materializing due to techno legal issues

10. Liquidated damages - uninsured risks. Damage recovery could not be passed on to vendors or consortium failure.

11. Contractual issues: vacuum in scoping. A condition arises towards which neither Contractor, nor Client takes the responsibility. Difference in perspectives resulting counter arguments.

12. Client unsatisfied on performances-claims/ revenue deductions

13. Manhours increased by $10-20 \%$

14. Raw materials cost increased, by 2-5\% (covered under escalation?)

15. Inefficiency surfaces man, machine and time losses (Reword)

16. Overheads increased. By $10-50 \%$

17. Sub contractor liquidity and delay in sourcing alternate.

18. Force Majeure events (Earth quake, floods, Tsunamis etc)

19. HSE issues (fatalities, injuries, accidents)

20. Lack of skilled labor / personnel

21. Inadequate / improper design leading to site modifications

22. Lack of coordination among engineering teams, fabricators, vendors and consortium of contributors

23. Improper planning (construction delay due to cyclones, monsoon etc) 
24. Government authority interference due to environmental issues

25. Inadequate construction supervision / management

26. Local population unrest/riots leading to stoppage of work.

27. TQs not properly raised during pre-bid

28. Process guarantees not covered properly during pre-bid

29. Important cost/schedule factors missed or heavily underestimated during pre-bid

30. Miss on cost of tools / S-W

31. Items/ studies to be outsourced missed during the bid

32. Commissioning delays because of engineering mistakes leading to LD clause

33. Several others, similar or part of above.

It is very obvious that very genuine reasons were produced rich of experience, but far from a definitive classification of risk. There could be hundreds and thousands of specific reasons, they all can not be studied and taken care of. Obvious duplication of reasons, overlaps in the reasons are due to different experience and outlook of the respondents. It is difficult to define these risks, hence the need to characterize them into categories and assign a fixed boundary of variation and possibilities to those group of causal factors or based on impact limitations.

\section{Characterize risks}

In EPC context, Risk can be simply defined as a factor that contributes to the escalation in pre-determined costs and schedule but remainsignored, dormant or underestimated during bid stage.

- Ignored, because of human negligence,

- Dormant because there could be thousands of reasons, which all can not be foreseen in advance. Every time there is anew factor emerging that was not experienced before in other projects or was so infrequent as if happening first time.

- Underestimated, because of lack of understanding of the extent of an activity and or poor understanding of the market dynamics.

Note that Risk has two aespects, one on the initiating cause side (ignored, dormant, and underestimated) and the other on result side (Costs and schedule estimates, goodwill, legal, reliability etc). Considering EPC Projects variability, there could be several dimensions which may categorize the risk. Risk characterization approach, in this paper, follows a simple two dimensional Risk Categories (Refer to Table 1):

- Controllability of the cause factor: Easy internal controls, Difficult external factors

- Tangibility of the resulting parameter: Directly Measurable or Unmeasurable costs and schedules. Challenge is in converting the intangibles into tangibles to exactly measure the risk levels.

Accordingly, Table 1 below indicates the Risk identification \& Characterization matrix:

Primarily four generic categories of Risks can be characterized:

\section{Tangible and Controllable:}

These are the Risks very much in hands of Project Manager and easy to foresee during bid stage. Depending on how well the project is split into distinctly identifiable cost and schedule entities, their variation may be ranged and impact estimated probabilistically even during Bid stage, which would serve as the reference scale during project execution. Example: Cost and schedule attached to 'Transportation of Gas turbines to the sites' is a tangible activity and its cost and schedule can be well established in arrange with presumed risks margins. It is possible that the bid considers this as an absolute cost ignoring the fact that the validity of vendor's backup cost is merely three months, which is likely to inflate, if project is executed after a year or two. Only base cost considered in bid not the risk.

\section{Tangible and Un-Controllable:}

These are the Risks that are measurable, but their variations may be due to external reasons, or macro economic reasons not easily expected. During bid stage a contingency margin normally addresses this type of Risks. Example: Transport cost was bid one year in advance and valid for three months only. A year later crude oil prices rocketed $50 \%$ upwards and shipping cost changed drastically. Crude prices are not in bidder's control but shipping costs are measurable and can be considered as proportional to crude oil prices.

\section{Intangible but Controllable:}

Sounds strange but, true, there are risks that are difficult to measure, but easy to control. Undefined causes resulting into costs and scheduled impact can be controlled by proper and systematic procedures and checklists. While in an unsystematic ways, if some important point is missed at the time of bid, it is difficult to say what risk has crept in surreptitiously - it may end up as a minor or major impact on costs/schedules. Unknown construction issues, which could be controlled if the subcontractor was involved during bidding stage, would come in this category. New cost entities emerge (of unknown tune) which was not at all considered in the beginning. 


\begin{tabular}{l|l}
$\begin{array}{l}\text { Risk Identification and } \\
\text { Characterization Matrix }\end{array}$ & \multicolumn{1}{|c}{ Internal Factors (Better Control) } \\
\hline $\begin{array}{l}\text { Impacts - Tangible \& Measurable } \\
\text { (Direct Cost, Time, Resources) }\end{array}$ & $\begin{array}{l}\text { Micronized cost and schedule components, } \\
\text { backed up from vendors. } \\
\text { For example: Cost of transportation missed } \\
\text { insurance attached to it, becomes a cost risk } \\
\text { later. }\end{array}$ \\
\hline $\begin{array}{l}\text { Impacts - Intangibles and Not } \\
\text { Measurable easily but Indirectly } \\
\text { affecting Cost Time, resources. } \\
\text { (Improper planning, unforeseen } \\
\text { issues, Goodwill, labor, riots etc,) }\end{array}$ & $\begin{array}{l}\text { Myopic vision on some factors, which in } \\
\text { directly affects the cost, schedule and resource } \\
\text { requirement of projects, such as company } \\
\text { shared culture, Labor issues, productivity etc. } \\
\text { This also includes profit centric strategists } \\
\text { that result in poor quality deliverables. Often } \\
\text { coupled with valid or invalid claims resulting } \\
\text { into client un satisfaction. }\end{array}$ \\
$\begin{array}{ll}\text { For example: If an EPC companies } \\
\text { underestimate the labor market, it may be } \\
\text { difficult to hire specialized skills on-time } \\
\text { resulting into delayed schedules. }\end{array}$ \\
\hline
\end{tabular}

External Factors (Live with OR Absorb impacts strategically)

Poor Focus on Macros and Poor adaption to business environment.

Poor Vendor/Subcon relationships also impacts costs and schedule. Worst case, may require change in vendor/Subcon at last moment
Most difficult to visualize. Macros often beyond control or predictions, Impacts heavy and un measurable.

For example: Ungodly events, of Tsunamis or Country destabilized, such as Libya and Egypt.

\section{Table 1 Risk Identification and Characterization}

Intangible and uncontrollable: This is the risk category, one has to live with and nothing much can be done - God Help! Example: Tsunamis, riots near fabrication yard. Major political upheaval stops the project for indefinite time etc.

Following this approach, Risks related to Micros or controllable include those which can be easily put into cost and schedule numbers with the help of internal manufacturing, engineering teams or with support from external subcontractors and vendors. Risks related to Intangible Micros are relatively difficult to estimates, but through characterization they may be put into one of those categories, which have a risk estimation premium associated with. Macros are those economic parameters controlled by governments, and may be estimated within range as well. Hence the paper would discuss these three categories of risk estimation.

\section{Risk breakdown}

an EPC Project has hundreds of thousands of activities to be taken care of. Which one would be a potential risk can not be foreseen always and is a complex issue. Identifying the risks is a first step prior to characterizing and measuring it. Project Scope and activities details of EPC Projects based on the systems and modules, provides a preliminary source of information to sketch out Tangible and Intangible Risk factors, which can be measurable (Refer Table 2). In this section we shall focus on tangible risk breakdown technique, and then characterize it by adding a potential range of variations in costs and schedules and possibilities attached to them. Intangible risk characterization shall be slightly different and shall be covered in next section.

FPSO is Floating Production, Storage $\&$ Offloading vessel used for deepwater offshore productions. An EPC project for FPSO has several phases of Engineering, Construction, Procurements, Transportation, Installations and Commissioning. The construction generally takes place at onshore fabrication yards with dry dock facilities. Pre-engineered and pre-fabricated modules of various units are fabricated at vendor's own sites and shipped to fabrication yard where the modules are assembled. Once the ship is ready to sail off, it is transported to the actually offshore site and installed.
Marine engineering takes car of the sub sea issues, installation, mooring stations and station keeping dynamic positioning and stability issues. Typically following Installations or sub components of complete Greenfield development are issued as separate EPC contract:

\section{Wellheads}

2. PLEM and sub sea pipelines

(Multiphase flowlines and Dry gas lines)

3. FPSO, HULL and risers.

4. Onshore facility for receiving and Onshore Transportation pipelines. 5. Shuttle tankers and floating hose systems for condensate offloading 6. Mooring systems

Any EPC activity has cost items and activity schedules available for project valuation and scheduling. These items are often backed by vendors, or in-house capabilities. Hence all the costs and schedule entities have initial bid level estimates. Due to backup information available it is also relatively easy to assign a tentative range of variation for these costs and schedule entities based on experience or with the help of vendors. 


\begin{tabular}{|c|c|c|c|c|c|}
\hline Activity Tables & Engineering & Procurement & $\begin{array}{l}\text { Construction } \\
\text { \& testing }\end{array}$ & $\begin{array}{l}\text { Transportation } \\
\text { \& Installation }\end{array}$ & $\begin{array}{l}\text { Pre-com and } \\
\text { commissioning }\end{array}$ \\
\hline & A & B & C & D & $\mathbf{E}$ \\
\hline \multicolumn{6}{|c|}{ Drilled and completed well with conductors } \\
\hline Item 1 & $1 \mathrm{~A}$ & $1 \mathrm{~B}$ & ${ }_{1 C} \mathrm{C}$ & $1 \mathrm{D}$ & $1 \mathrm{E}$ \\
\hline Item2 & $2 \mathrm{~A}$ & $2 \mathrm{~B}$ & $2 \mathrm{C}$ & $2 \mathrm{D}$ & $2 \mathrm{E}$ \\
\hline Item 3 & $3 \mathrm{~A}$ & $3 B$ & $3 \mathrm{C}$ & $3 \mathrm{D}$ & $3 \mathrm{E}$ \\
\hline \multicolumn{6}{|c|}{ Wellheads or cluster of Wells connected via pipelines } \\
\hline Item 1 & $4 \mathrm{~A}$ & $4 \mathrm{~B}$ & ${ }_{4} \mathrm{C}$ & 4D & $4 \mathrm{E}$ \\
\hline Item2 & $5 \mathrm{~A}$ & $5 \mathrm{~B}$ & ${ }_{5} \mathrm{C}$ & $5 \mathrm{D}$ & $5 \mathrm{E}$ \\
\hline Item 3 & $6 \mathrm{~A}$ & $6 B$ & $6 C$ & $6 \mathrm{D}$ & $6 \mathrm{E}$ \\
\hline \multicolumn{6}{|c|}{$\begin{array}{l}\text { Multiphase Flowlines transferring fluids from wells to } \\
\text { FPSO }\end{array}$} \\
\hline Item 1 & $7 \mathrm{~A}$ & $7 \mathrm{~B}$ & $7 \mathrm{C}$ & $7 \mathrm{D}$ & $7 \mathrm{E}$ \\
\hline Item2 & $8 \mathrm{~A}$ & $8 \mathrm{~B}$ & $8 C$ & $8 \mathrm{D}$ & $8 \mathrm{E}$ \\
\hline Item 3 & $9 \mathrm{~A}$ & $9 B$ & $9 \mathrm{C}$ & $9 D$ & $9 \mathrm{E}$ \\
\hline \multicolumn{6}{|l|}{ FPSO - Topsides } \\
\hline Item 1 & $10 \mathrm{~A}$ & $10 B$ & $10 \mathrm{C}$ & $10 \mathrm{D}$ & $10 \mathrm{E}$ \\
\hline Item2 & $11 \mathrm{~A}$ & $11 \mathrm{~B}$ & $11 \mathrm{C}$ & $11 \mathrm{D}$ & $11 \mathrm{E}$ \\
\hline Item 3 & $12 \mathrm{~A}$ & $12 \mathrm{~B}$ & $12 \mathrm{C}$ & $12 \mathrm{D}$ & $12 \mathrm{E}$ \\
\hline Item 4 & $13 \mathrm{~A}$ & $13 B$ & ${ }_{13} \mathrm{C}$ & $13 \mathrm{D}$ & $13 \mathrm{E}$ \\
\hline Item 5 & $14 \mathrm{~A}$ & $14 \mathrm{~B}$ & $14 \mathrm{C}$ & $14 \mathrm{D}$ & $14 \mathrm{E}$ \\
\hline Item 6 & $15 \mathrm{~A}$ & $15 B$ & ${ }_{15} \mathrm{C}$ & $15 \mathrm{D}$ & $15 \mathrm{E}$ \\
\hline Item 7 & $16 \mathrm{~A}$ & $16 B$ & $16 C$ & $16 \mathrm{D}$ & $16 \mathrm{E}$ \\
\hline Item 8 & $17 \mathrm{~A}$ & $17 \mathrm{~B}$ & ${ }_{17} \mathrm{C}$ & $17 \mathrm{D}$ & $17 \mathrm{E}$ \\
\hline Item 9 & $18 \mathrm{~A}$ & $18 \mathrm{~B}$ & $18 \mathrm{C}$ & $18 \mathrm{D}$ & $18 \mathrm{E}$ \\
\hline \multicolumn{6}{|c|}{ FPSO - Hull-side, structural stability/ fatigue } \\
\hline Item 1 & $19 \mathrm{~A}$ & $19 B$ & $19 \mathrm{C}$ & $19 \mathrm{D}$ & $19 \mathrm{E}$ \\
\hline Item2 & $20 \mathrm{~A}$ & $20 B$ & $20 \mathrm{C}$ & $20 \mathrm{D}$ & $20 \mathrm{E}$ \\
\hline Item 3 & $21 \mathrm{~A}$ & $21 \mathrm{~B}$ & $21 \mathrm{C}$ & $21 \mathrm{D}$ & $21 \mathrm{E}$ \\
\hline Item 4 & $22 \mathrm{~A}$ & $22 B$ & $22 \mathrm{C}$ & $22 \mathrm{D}$ & $22 \mathrm{E}$ \\
\hline Item 5 & $23 \mathrm{~A}$ & $23 B$ & $23 \mathrm{C}$ & $23 \mathrm{D}$ & $23 \mathrm{E}$ \\
\hline Item 6 & $24 \mathrm{~A}$ & $24 B$ & $24 \mathrm{C}$ & $24 \mathrm{D}$ & $24 \mathrm{E}$ \\
\hline \multicolumn{6}{|c|}{$\begin{array}{l}\text { FPSO - Station keeping \& Mooring analysis (with SM/ } \\
\text { SPM/CALM/SALM) }\end{array}$} \\
\hline Item 1 & $25 \mathrm{~A}$ & $25 B$ & $25 \mathrm{C}$ & $25 \mathrm{D}$ & $25 \mathrm{E}$ \\
\hline Item2 & $26 \mathrm{~A}$ & 26B & $26 C$ & $26 \mathrm{D}$ & $26 \mathrm{E}$ \\
\hline Item 3 & $27 \mathrm{~A}$ & $27 B$ & $27 \mathrm{C}$ & $27 \mathrm{D}$ & $27 \mathrm{E}$ \\
\hline \multicolumn{6}{|c|}{ Dry Gas Pipelines from FPSO to Onshore ORF } \\
\hline Item 1 & $28 \mathrm{~A}$ & $28 B$ & $28 C$ & $28 \mathrm{D}$ & $28 \mathrm{E}$ \\
\hline Item2 & $29 A$ & $29 B$ & $29 \mathrm{C}$ & $29 D$ & $29 \mathrm{E}$ \\
\hline Item 3 & $30 \mathrm{~A}$ & $30 \mathrm{~B}$ & $30 \mathrm{C}$ & $30 \mathrm{D}$ & $30 \mathrm{E}$ \\
\hline \multicolumn{6}{|c|}{$\begin{array}{l}\text { Condensate transferring to shuttle tankers OR } \\
\text { Pipeline to ORF }\end{array}$} \\
\hline Item 1 & $31 \mathrm{~A}$ & $31 \mathrm{~B}$ & $31 \mathrm{C}$ & $31 \mathrm{D}$ & $31 \mathrm{E}$ \\
\hline Item2 & $32 \mathrm{~A}$ & $32 \mathrm{~B}$ & $32 \mathrm{C}$ & $32 \mathrm{D}$ & $32 \mathrm{E}$ \\
\hline Item 3 & $33 \mathrm{~A}$ & $33 B$ & $33 \mathrm{C}$ & $33 \mathrm{D}$ & $33 \mathrm{E}$ \\
\hline \multicolumn{6}{|c|}{ Onshore Receiving Facilities ORF } \\
\hline Item 1 & $34 \mathrm{~A}$ & $34 B$ & $34 \mathrm{C}$ & $34 \mathrm{D}$ & $34 \mathrm{E}$ \\
\hline Item2 & $35 \mathrm{~A}$ & $35 \mathrm{~B}$ & $35 \mathrm{C}$ & $35 \mathrm{D}$ & $35 \mathrm{E}$ \\
\hline Item 3 & $36 \mathrm{~A}$ & $36 B$ & $36 C$ & $36 \mathrm{D}$ & $36 \mathrm{E}$ \\
\hline
\end{tabular}

Table 2 EPC Risk Breakdown through Activity Identification 
Considering the case of FPSO, The first step is to identify the items or modules to be incorporated in designs. As each of these modules shall go a full scale EPC process, starting from Engineering, Procurement order placing (if not the lead item, ordered by client in advance), Delivery involving transportations, Integration and Assembly at main construction yard, final sail-off and Installation offshore. Therefore most of the items can be further split into these activities as shown in table 2. This is about all equipments and modules located in Topsides, hull, wellhead platforms' and SBM. Topsides shall have multi layered decks comprising equipments and units required for various gas processing systems, sub systems and utilities, power generation, flare systems, Acid gas systems, compression, dew pointing etc. Typically Items, split into the EPC phase activities as showing in Table 2 below constitute an entity effecting costs or schedule. For schedule, each of the activity is dependant on prior activity if linked. One of these links of activities shall form the critical path, to be determined using project scheduling separately. There could still be some activities which normally are not in critical path but delays beyond a limit brings them into critical path, say category 2 items, former being 1 . Hence Table 2 indicates how to convert the big project into smaller activity models following items and activities together. For example $1 \mathrm{~A}$ is an activity with a cost and Schedule attached to it, say $1 \mathrm{~A}-\mathrm{C}$ and $1 \mathrm{~A}-\mathrm{S}$ :

\section{Identify \& measuring tangible risks}

Each of the activities shown in Table 2 has an associated cost and schedule number. All of these are tangible numbers as all of them are backed by vendor or in-house experiences and can be predicted in narrow range for their variations. Any risk arising out of the escalation of these entities shall be considered as tangible Risks. The paper can not discuss all the systems; however as the purpose is to delineate a scheme for Risk analysis, only a subunit of topsides with limited equipment and it's EPC phases shown in blue shade and double border shall be considered for further illustration. Table 3 shows that typical nine modules are further converted into cost and schedule entities, as shown in left most columns. A module has its costs and schedule for engineering, procurement, delivery times to fabrication yard, then assembly, integration and construction at fabrication yards, transportation \& installation and commissioning etc. Eventually it results into 45 cost and schedule entities as reflected in left column in Table 3. Analysis further assumes two unplanned activities and variation, which is likely to emerge during final engineering stage. Each of these activities have a pre determined cost and schedule numbers either given by vendor or generated in-house, however each of them are subject to change and vary within a range. $A$ preliminary range may be fixed based on experience for each of the cost and schedule entities, say minimum could be $10-20 \%$ less than Pre-determined Normal value used for the bid, and maximum could be $10-30 \%$ more. A more in-depth experience can be used to develop a Markov relationship with those entities. The spread sheet used for this paper considers several such empirical Markov chains. The MS Excel spread sheet uses Risksim RANDTRIANGULAR function to gener- ate the probabilistic figure for each of the costs and schedule entities. As the spread sheet is build up, 47 Actual cost and 47 Actual schedule entities are reflected in Table 3 right side columns which shall be simulated using Monte Carlo Risk Simulations on MS Excel about 1000 times. Each run generates 47 probabilistic cost and schedule numbers, which is averaged out to generate the most probabilistic numbers for each of 47 costs and schedules (David T. Hulett, 2004, Kim Bang Salling, and Sii, H.S., Wang, J., and Ruxton, T., 2003). This in turn determines the most probabilistic estimates of Project value and Project Schedule, considering tangible risks only. Intangible risks yet to be discussed.

Note that, each of the activities schedule is assigned a number of 0,1 , or 2 , where 1 is assigned to activities that fall in Critical path, 2 is assigned to activities which are not normally in critical path but have a max and min periods attached to it. These activities can absorb up to $75 \%$ of maximum delays anticipated, after which they become a critical path activities, this is a kind of Markov Relationship built into the spreadsheets. o is assigned to activities which are far from critical schedule. Together 1000 runs of the case provides the most probabilistic project costs and schedules based on tangible risks as given in Table 3. The critical path schedule changes considering long lead item schedule variations also analyzed which are usually not on critical path until crossing more than $75 \%$ of max expected delays.

After running the Monte Carlo simulations on tangible cost and schedule numbers, the results are shown in Table 3. 


\begin{tabular}{|c|c|c|c|c|c|c|c|c|c|c|c|c|}
\hline \multirow{3}{*}{$\begin{array}{l}\text { SI } \\
\text { No. }\end{array}$} & \multirow{3}{*}{$\begin{array}{l}\text { Tangible and measurable } \\
\text { Description }\end{array}$} & \multirow{2}{*}{\multicolumn{3}{|c|}{$\begin{array}{l}\text { Costs (including all resources) } \\
\text { USD } 000 \\
\text { Min Nor Max }\end{array}$}} & \multirow{2}{*}{\multicolumn{3}{|c|}{ 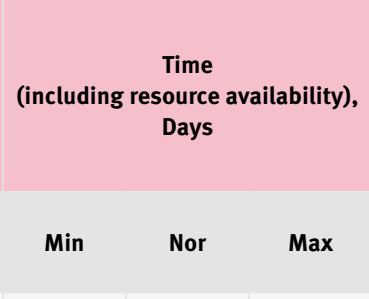 }} & \multirow{3}{*}{$\begin{array}{l}\text { 1: Critical } \\
\text { Path } \\
\text { 2: 2nd } \\
\text { CP } \\
\text { o: Not a } \\
\text { CP } \\
\text { (Note 2) }\end{array}$} & \multicolumn{4}{|c|}{$\begin{array}{l}\text { Note2: } 75 \% \text { on Non critical path means, that } \\
75 \% \text { of maximum variation foreseen can be } \\
\text { absorbed by the Project schedule, exceeding } \\
\text { which makes the activity critical and project } \\
\text { schedule is impacted. }\end{array}$} \\
\hline & & & & & & & & & $\begin{array}{l}\text { Actual } \\
\text { Costs }\end{array}$ & $\begin{array}{c}\% \\
\text { change }\end{array}$ & $\begin{array}{c}\text { Actual } \\
\text { Duration }\end{array}$ & $\begin{array}{l}\text { Impact } \\
\text { on } \\
\text { Schedule }\end{array}$ \\
\hline & & $\begin{array}{r}80-95^{*} \\
\text { of } P_{50}\end{array}$ & $\begin{array}{r}\text { Base } \\
\text { Quote }\end{array}$ & $\begin{array}{r}105- \\
1405 \% \\
\text { of } P_{50}\end{array}$ & $\begin{array}{c}80-95^{*} \\
\text { of } P_{50}\end{array}$ & $\begin{array}{r}\text { Base } \\
\text { scheduel }\end{array}$ & $\begin{array}{c}105^{-} \\
13 \%^{*} \\
\text { of } P_{50}\end{array}$ & & \$'ooo & & Days & \\
\hline 1 & Engineering 6 & 47 & 52 & 63 & 80.60 & 90 & 98.51 & 1 & 58.92 & $0.00 \%$ & 87.96 & 0.00 \\
\hline 2 & Engineering 5 & 52 & 65 & 72 & 53.60 & 67 & 73.70 & 1 & 56.67 & $0.00 \%$ & 65.11 & 0.00 \\
\hline 3 & Engineering 2 & 293 & 345 & 449 & 38.25 & 45 & 49.50 & 2 & 354.09 & $0.00 \%$ & 43.41 & 6.29 \\
\hline 4 & Engineering 8 & 6 & 6 & 9 & 40.73 & 45 & 49.78 & 1 & 6.63 & $0.00 \%$ & 45.45 & 0.19 \\
\hline 5 & Engineering 4 & 135 & 150 & 188 & 74.70 & 83 & 91.30 & 0 & 164.40 & $0.00 \%$ & 81.86 & 0.00 \\
\hline 6 & Engineering 9 & 2 & 3 & 3 & 16.06 & 20 & 22.08 & 2 & 2.61 & $0.00 \%$ & 19.04 & 2.48 \\
\hline 7 & Engineering 7 & 31 & 37 & 39 & 81.28 & 96 & 105.18 & 2 & 36.30 & $0.00 \%$ & 95.81 & 16.93 \\
\hline 8 & Engineering 3 & 211 & 234 & 328 & 112.50 & 125 & 137.50 & 0 & 218.0 & $0.00 \%$ & 116.37 & 0.00 \\
\hline 9 & Engineering 1 & 359 & 399 & 479 & 70.20 & 78 & 85.80 & 2 & 433.3 & $0.01 \%$ & 74.83 & 10.48 \\
\hline 10 & Procurement Cost 6 & 8,000 & 10,000 & 11,000 & 48.67 & 61 & 66.92 & 0 & 9,957 & $-0.01 \%$ & 55.05 & 0.00 \\
\hline 11 & Procurement Cost 7 & 6,375 & 7,500 & 9,750 & 68.98 & 81 & 89.27 & 2 & 7,323 & $-0.03 \%$ & 76.09 & 9.14 \\
\hline 12 & Procurement Cost 3 Lead 2 & 52,200 & 58,000 & 78,300 & 206.68 & 230 & 252.61 & 2 & 71,456 & $2.49 \%$ & 215.68 & 26.22 \\
\hline 13 & Procurement Cost 8 & 6,300 & 7,000 & 8,750 & 5.74 & 6 & 7.01 & 1 & 6,637 & $-0.07 \%$ & 5.93 & 0.00 \\
\hline 14 & Procurement Cost 1 Lead 3 & 153,000 & 170,000 & 195,500 & 125.81 & 157 & 172.99 & 2 & 168,282 & $-0.32 \%$ & 147.71 & 17.97 \\
\hline 15 & Procurement Cost 5 & 25,500 & 30,000 & 31,500 & 25.24 & 30 & 32.66 & 1 & 29,988 & $0.00 \%$ & 26.20 & 0.00 \\
\hline 16 & Procurement Cost 4 & 44,100 & 49,000 & 68,600 & 52.20 & 58 & 63.80 & 1 & 59,574 & $1.96 \%$ & 53.96 & 0.00 \\
\hline 17 & Procurement Cost 2 Lead 1 & 117,000 & 130,000 & 156,000 & 252.00 & 280 & 308.00 & 2 & 125,285 & $-0.87 \%$ & 262.13 & 31.13 \\
\hline 18 & Procurement Cost 9 & 5,415 & 5,700 & 6,840 & 36.00 & 45 & $49 \cdot 50$ & 1 & $6,369.80$ & $0.12 \%$ & 45.41 & 0.41 \\
\hline 19 & Construction and SAT & 65 & 77 & 100 & 30.63 & 36 & 39.64 & 1 & 82.05 & $0.00 \%$ & 36.13 & 0.09 \\
\hline 20 & Construction and SAT & 22 & 25 & 33 & 60.56 & 67 & 74.02 & 1 & 25.82 & $0.00 \%$ & 67.59 & 0.30 \\
\hline 21 & Construction and SAT & 25 & 28 & 35 & 84.85 & 94 & 103.71 & 2 & 34.27 & $0.00 \%$ & 87.17 & 9.38 \\
\hline 22 & Construction and SAT & 10 & 12 & 14 & 71.86 & 90 & 98.81 & 2 & 13.69 & $0.00 \%$ & 90.26 & 16.16 \\
\hline 23 & Construction and SAT & 75 & 88 & 93 & 38.25 & 45 & $49 \cdot 50$ & 2 & 87.13 & $0.00 \%$ & 45.23 & 8.11 \\
\hline 24 & Construction and SAT & 45 & 50 & 70 & 12.36 & 14 & 15.11 & 0 & 55.35 & $0.00 \%$ & 14.85 & 0.00 \\
\hline 25 & Construction and SAT & 19 & 21 & 26 & 2.76 & 3 & 3.37 & o & 21.25 & $0.00 \%$ & 2.94 & 0.00 \\
\hline 26 & Construction and SAT & 49 & 61 & 67 & 69.96 & 87 & 96.19 & 2 & 62.99 & $0.00 \%$ & 88.62 & 16.48 \\
\hline 27 & Construction and SAT & 60 & 71 & 92 & 64.05 & 75 & 82.88 & 2 & 80.27 & $0.00 \%$ & 71.01 & 8.84 \\
\hline 28 & Transportation \& Installation & 1,800 & 2,000 & 2,700 & 61.64 & 68 & 75.33 & 1 & $2,184 \cdot 38$ & $0.03 \%$ & 71.37 & 2.88 \\
\hline 29 & Transportation \& Installation & 1,350 & 1,500 & 1,875 & 84.69 & 94 & 103.51 & 2 & $1,613.80$ & $0.02 \%$ & 96.98 & 19.35 \\
\hline 30 & Transportation \& Installation & 9,280 & 11,600 & 13,340 & 8.01 & 10 & 11.01 & 1 & $11,919.63$ & $0.06 \%$ & 10.38 & 0.37 \\
\hline 31 & Transportation \& Installation & 1,190 & 1,400 & 1,470 & 55.37 & 65 & 71.65 & 1 & $1,369.16$ & $-0.01 \%$ & 63.81 & 0.00 \\
\hline 32 & Transportation \& Installation 2 & 15,300 & 17,000 & 23,800 & 19.29 & 21 & 23.58 & 0 & $17,671.87$ & $0.12 \%$ & 20.88 & 0.00 \\
\hline 33 & Transportation \& Installation & 5,400 & 6,000 & 7,200 & 4.61 & 5 & 5.63 & o & $5,951.41$ & $-0.01 \%$ & 5.21 & 0.00 \\
\hline 34 & Transportation \& Installation & 7,840 & 9,800 & 10,780 & 2.16 & 3 & 2.97 & 0 & $8,612.93$ & $-0.22 \%$ & 2.76 & 0.00 \\
\hline 35 & Transportation \& Installation 1 & 16,575 & 19,500 & 25,350 & 37.14 & 44 & 48.06 & o & $19,893.55$ & $0.07 \%$ & 47.25 & 0.00 \\
\hline 36 & Transportation \& Installation & 1,026 & 1,140 & 1,539 & 60.82 & 68 & 74.34 & 2 & $1,127.90$ & $0.00 \%$ & 68.98 & 13.23 \\
\hline 37 & Pre-Com/ Commissioning & 33 & 37 & 46 & 27.00 & 30 & 33.00 & 2 & 35.58 & $0.00 \%$ & 27.74 & 2.99 \\
\hline 38 & Pre-Com/Commissioning & 22 & 27 & 31 & 4.89 & 6 & 6.72 & 0 & 28.84 & $0.00 \%$ & 6.31 & 0.00 \\
\hline 39 & Pre-Com/ Commissioning & 78 & 91 & 96 & 18.91 & 22 & 24.48 & 0 & 90.21 & $0.00 \%$ & 23.37 & 0.00 \\
\hline 40 & Pre-Com/ Commissioning & 72 & 80 & 111 & 49.83 & 55 & 60.91 & 0 & 79.97 & $0.00 \%$ & 57.53 & 0.00 \\
\hline 41 & Pre-Com/ Com support vessels & 319 & 354 & 425 & 27.40 & 30 & 33.48 & o & 338.29 & $0.00 \%$ & 28.55 & 0.00 \\
\hline 42 & Pre-Com/ Com LQ barge & 176 & 220 & 242 & 24.64 & 31 & 33.88 & 0 & 224.15 & $0.00 \%$ & 27.02 & 0.00 \\
\hline 43 & Pre-Com/Commissioning & 41 & 48 & 63 & 7.34 & 9 & 9.50 & 1 & 59.88 & $0.00 \%$ & 9.11 & 0.47 \\
\hline 44 & Pre-Com/ Commissioning & 51 & 57 & 76 & 25.38 & 28 & 31.02 & 1 & 67.20 & $0.00 \%$ & 28.99 & 0.79 \\
\hline 45 & Pre-Com/ Commissioning & 39 & 44 & 54 & 11.64 & 13 & 14.22 & 1 & 47.06 & $0.00 \%$ & 12.89 & 0.00 \\
\hline 46 & Unplanned Activity 1 (note1) & 60 & 75 & 86 & 21.23 & 27 & 29.19 & 1 & 80.84 & $0.00 \%$ & 26.45 & 0.00 \\
\hline \multirow[t]{3}{*}{47} & Unplanned Variation 2(note1) & 123 & 145 & 152 & 31.46 & 37 & 40.71 & 1 & 132.99 & $0.00 \%$ & 36.08 & 0.00 \\
\hline & Total & 480,171 & 540,042 & 657,834 & 819 & 946 & 1041 & & 558,197 & & 692.82 & 220.67 \\
\hline & & & & $21.8 \%$ & & & & & $3.36 \%$ & $\begin{array}{r}\text { Actual } \\
\text { Schedule }\end{array}$ & 913.49 & $31.85 \%$ \\
\hline
\end{tabular}




\section{Identify \& measure intangible risks}

It is easy to identify the tangible risks as basis is much clearer and supporting facts can be made available from vendor or previous experience. However, Intangible risks have no boundaries and not enough experience based backup, as every project is full of new issues and experiences beyond the human imaginations. As shown in the expert's survey, the risk factors are an explanation unpredictable and immeasurable and display lack of clarity in their categorization. For example, Transportation issue and non-availability of resources was also seen as construction issue at grand level. Precise boundaries could not be established at this stage, hence the challenge. Risk characterization as in previous sections helps in establishing a group of or type of risks into a category, the impact of which can be ranged and put into numbers. An attempt was made, in this direction, to classify and categorize the intangible risks based on their causal factors as well as qualitative consequential scenarios. 15 intangible risks were categorized, such that specific risks related to any project may be placed into one of these categories. An indicative probability of their occurrence and tentative impact levels on costs and schedule was qualitatively established. Project scheduling referred to identify, whether the activities are falling on critical path or not. All of these quiet subjective to projects, companies, and experience of analysts. The Impact perceived for each activity may change from company to company based on their strategic strengths and weaknesses, and should be considered as design basis by a collective project team. The purpose of this paper is to provide a schematic way to appreciate risk during bid stage, hence Numbers are being assumed to chalk-out the procedure and illustrations:

1 Re-work due to Poor Quality Engineering,
- Possibility $10 \%$

- Max Cost impact, $0.5 \%$

- Max schedule Impact, $5 \%$

- Critical Path - yes

- Spread Exponential

2 Non Availability of External Resources: Barges, support vessels/secondary arrangements deemed necessary at the nick of time

- Possibility, $2 \%$

- Max cost impact, $8 \%$

- Max schedule impact, $16 \%$

- Critical path - yes

3 Non Availability of Raw materials, MOC, Skilled labor, specialists \& other logistic issues

- Possibility, $5 \%$

- Max cost impact, $3 \%$

- Max schedule impact, $5 \%$

- Critical path - yes

4 Client's Unsatisfied Minor category,

- Possibility $5 \%$

- Max Cost Impact (limited to this project amounting to $0.1 \%$ )

- Max Schedule Impact, NIL

- Critical path - No

5 - Client's unsatisfied Major,

- Possibility $0.5 \%$

- Max Cost Impact (extends to

Future projects amounting to $25 \%$ of project value)

- Max Schedule Impact, $2 \%$, acceptance issue

- Non critical path

6 Unexpected Expediting Escalation - Possibility, $2 \%$

- Max cost impact, 10 person 60 days@ 200 \$/day

- Max schedule Impact $5 \%$

- $75 \%$ of variation on Non critical

path, exceeding which brings into Critical path

7 Sub contractor issues/ expediting and sourcing alternates at higher cost and time.

- Possibility $10 \%$

- Cost impact, min, normal, max

$=2 \%, 4 \%, 9 \%$ randomly

- Schedule impact, 8, 15, 6o days, randomly
- Critical path - yes

8 HSE issues Major, $>10$ fatalities,

- Possibilities $0.1 \%$,

- Max cost impact, $10 \%$,

- Schedule impact, $20 \%$

- Critical path

9 HSE issues Minor, 1-2 fatalities,

- Possibilities 5\%,

- Max cost impact $1 \%$,

- Schedule impact $5 \%$

- $75 \%$ on non critical path

10 Improper planning - clause

missed on high importance items,

- Possibility $2 \%$

- Max cost impact $8 \%$,

- Max schedule impact 10\%

- Critical path - yes

11 Improper planning - clause missed on Medium importance items,

- Possibility $5 \%$

- Max cost impact $2 \%$

- Max schedule impact $10 \%$

- $75 \%$ non critical path

12 Improper planning - clause

missed on Low importance items,

- Possibility $10 \%$

- Max cost impact $0.1 \%$

- Max schedule impact $1 \%$

- Non critical path

13 Constructability issues-Major \&

Critical: Unforeseen and emerged during engineering/ construction

/ integration,

- Possibility $5 \%$

- Max cost impact $5 \%$,

- Schedule impact $5 \%$

- Critical path - yes

14 Constructability issues-Minor

\& Non critical: Emerged during engineering/construction/

integration,

- Possibility $10 \%$

- Cost impact $1 \%$

- Schedule impact $1 \%$

- $75 \%$ non critical path

15 Local population unrest / riots leading to stoppage of work.

- Possibility $1 \%$

- Max cost impact, $3 \%$

- Max schedule impact $10 \%$

- Critical path-yes 
Exponential spreads of costs and schedule risks were formulated using RANDEXPONENTIAL functions in Risksim, such that every single run produced a randomly generated number governed by exponential curves. Exponential spreads best reflect the distribution of highly volatile intangible risks as their max limits are open ended and can not be predicted accurately; even they can cross the maximum expect variations too in an open and unending range; there is no true maximum. Exponential formulae is created to generate exponential curves that has a mean value close to the normal and tentative figures predicted, but still capable of throwing large variation even beyond the maximum expected by human minds.
The above numbers were built into the Excel spreadsheet and Intangibles were converted into tangible numbers categorically. Monte Carlo Simulations were run with 1000 cases to generate $P_{50}, P_{75}, P_{90}$ probabilistic estimates of Project Value and Project Schedule wetted with Tangible as well as Intangible Risks. The results are shown in Table 4.

\section{$Y=$ 'Normal value * RANDEXPONENTIAL $(1 / \lambda)$, where $1 / \lambda=($ Normal $/$ Maximum)}

All the above 15 risk factors are exponentially distributed, except the subcontractor issues, which is actually a hybrid factor in the sense that, it has a basis with previous subcontractor or same subcontractor pricing, but due to unexpected reasons the estimates escalate and therefore in a range, presumably $2-9 \%$ impact on costs and 8-60 days on schedule, as indicated in item 7 above. Note that several of the specific reasons provided by survey Respondents are covered in one or more of above categories:

- TQs not properly raised during pre-bid

- Process guarantees not covered properly during pre-bid

- Items missed or underestimated during pre-bid

- Miss on cost of tools / S-W

- Items/ studies to be outsourced missed during the bid

- Commissioning /engineering mistakes leading to LD clause

- Manhours increased

- Raw materials cost escalation

- Lack of skilled labor / personnel

- Inadequate / improper design leading to site modifications

- Inadequate construction supervision / management

- Un godly events, man, machine and time losses

- Force majeure events (earth quake, floods etc)

- Government authority/ Political interference covered in Improper planning covered in Improper planning covered in Improper planning covered in Improper planning covered in Improper planning covered in repeat work covered in repeat work covered in item costs Covered in construction issues, Covered in construction issues, Covered in construction issues, Covered in HSE Not considered /Impractical Political Not covered 


\begin{tabular}{|c|c|c|c|c|c|c|c|c|c|}
\hline 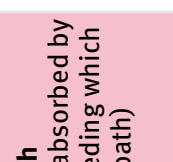 & 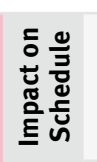 & & $\tilde{\tilde{\sigma}}$ & $\underset{\sim}{\sim}$ & $\stackrel{\infty}{\sim} \underset{\sim}{\sim}$ & $\begin{array}{l}0 \\
\text { d }\end{array}$ & $\stackrel{\circ}{\circ}$ & $\stackrel{\circ}{\circ}$ & $\stackrel{\circ}{\stackrel{\leftrightarrow}{\rightarrow}}$ \\
\hline 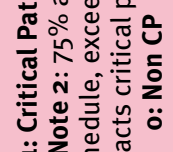 & 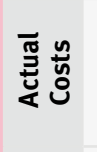 & ¿ & 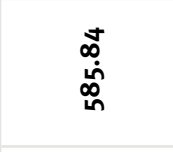 & 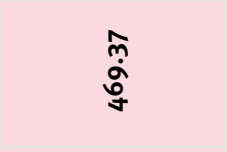 & 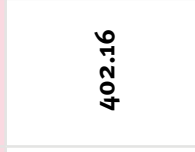 & $\stackrel{\infty}{=}$ & $\begin{array}{l}\overrightarrow{0} \\
\stackrel{\leftrightarrow}{\vec{H}}\end{array}$ & $\stackrel{\text { Nิ }}{ }$ & 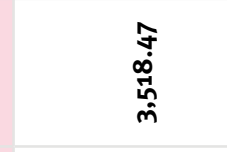 \\
\hline 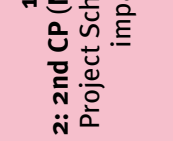 & 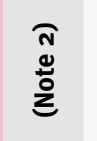 & & H & H & . & 。 & $\circ$ & N & . \\
\hline 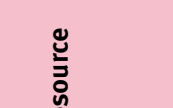 & $\frac{\times}{\tilde{c}}$ & & q & g & q & $a$ & $\stackrel{\infty}{=}$ & $\stackrel{\infty}{=}$ & 吕 \\
\hline 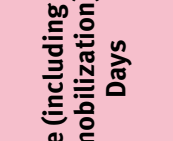 & $\stackrel{\grave{z}}{z}$ & 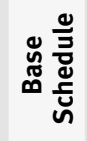 & $\tilde{a}$ & Nू & $\underset{\sim}{\infty}$ & $\stackrel{0}{0}$ & $\stackrel{\circ}{\circ}$ & $\stackrel{\circ}{\circ}$ & $\Rightarrow$ \\
\hline 离 & $\frac{5}{\Sigma}$ & & $\stackrel{n}{\circ}$ & $\stackrel{m}{0}$ & $\stackrel{0}{\circ}$ & $\stackrel{\circ}{\circ}$ & $\stackrel{\circ}{\circ}$ & $\stackrel{\circ}{\circ}$ & $\stackrel{\circ}{\infty}$ \\
\hline$\frac{\underline{y}}{\bar{z}}$ & $\alpha^{2}$ & & $\tilde{\wp}$ & î̀ & 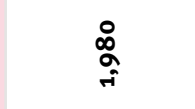 & $\Xi$ & : & 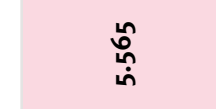 & ळ \\
\hline 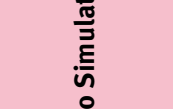 & $a^{k}$ & & $\stackrel{\text { ळ }}{\infty}$ & ț & $\underset{ন}{\infty}$ & $\stackrel{\circ}{m}$ & $\stackrel{\leftrightarrow}{a}$ & 吕 & 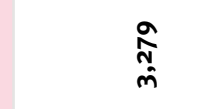 \\
\hline 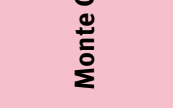 & $a^{2}$ & & $\frac{N}{N}$ & 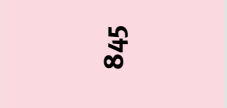 & $\underset{\Phi}{\tilde{D}}$ & $\hat{a}$ & $\overrightarrow{\mathrm{s}}$ & 芦 & $\begin{array}{c}\widehat{0} \\
\stackrel{i}{i}\end{array}$ \\
\hline 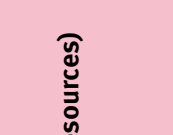 & $\stackrel{\text { 产 }}{2}$ & & 号 & 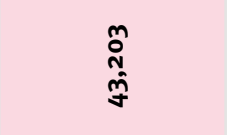 & تهِّ & 品 & 总 & $\stackrel{\pi}{\pi}$ & 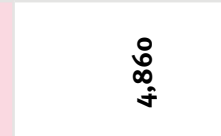 \\
\hline 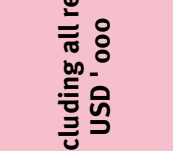 & $\bar{z}$ & 怘 & 节 & 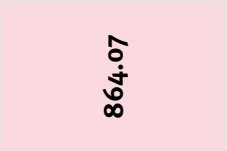 & $\begin{array}{l}\stackrel{\circ}{\dot{\phi}} \\
\stackrel{\infty}{\infty}\end{array}$ & $\stackrel{\circ}{i}$ & 㝘 & $\underset{\text { i }}{4}$ & $\underset{d}{\circ}$ \\
\hline$\frac{\mathrm{m}}{3}$ & $\frac{\Sigma}{\Sigma}$ & & $\stackrel{R}{i}$ & 常 & $\stackrel{\circ}{\stackrel{\infty}{\infty}}$ & $\hat{\check{O}}$ & مُ & 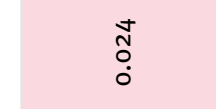 & 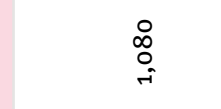 \\
\hline 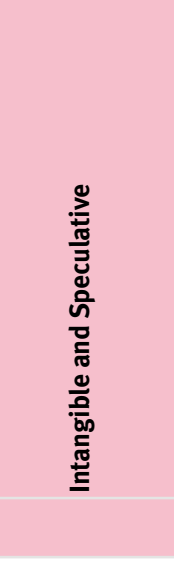 & 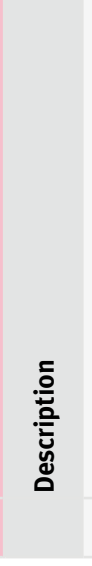 & 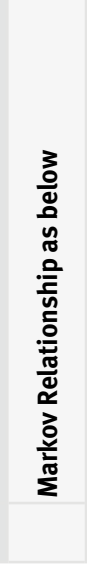 & 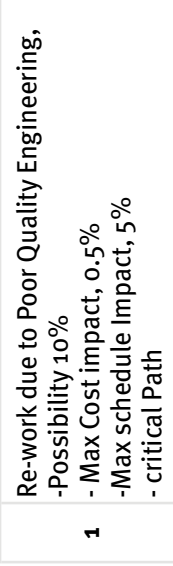 & 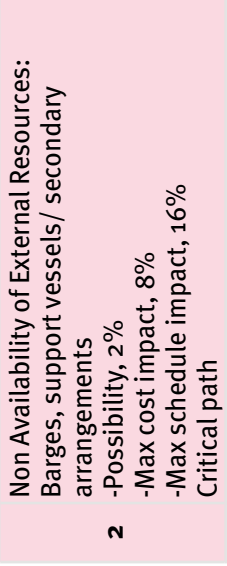 & 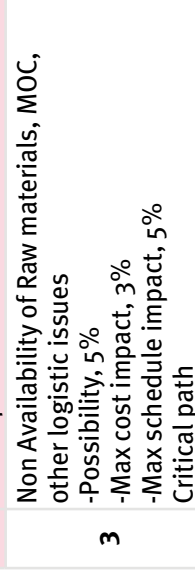 & 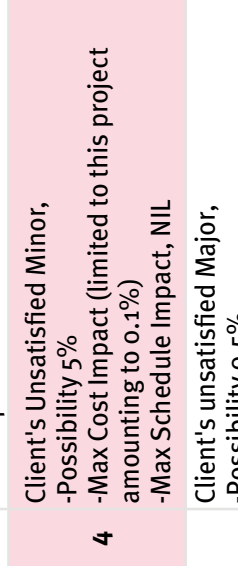 & 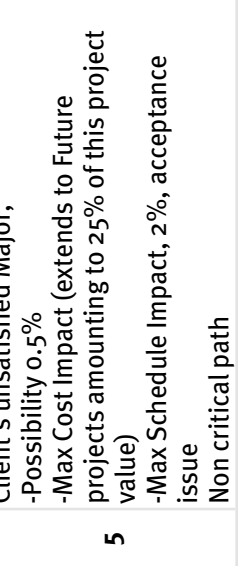 & 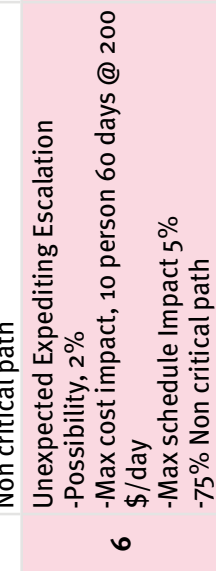 & 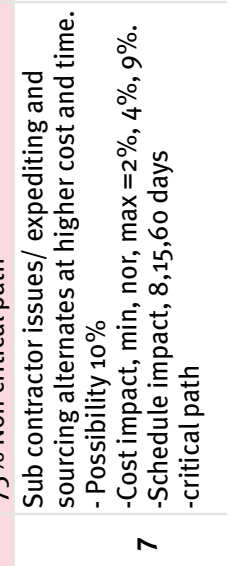 \\
\hline
\end{tabular}




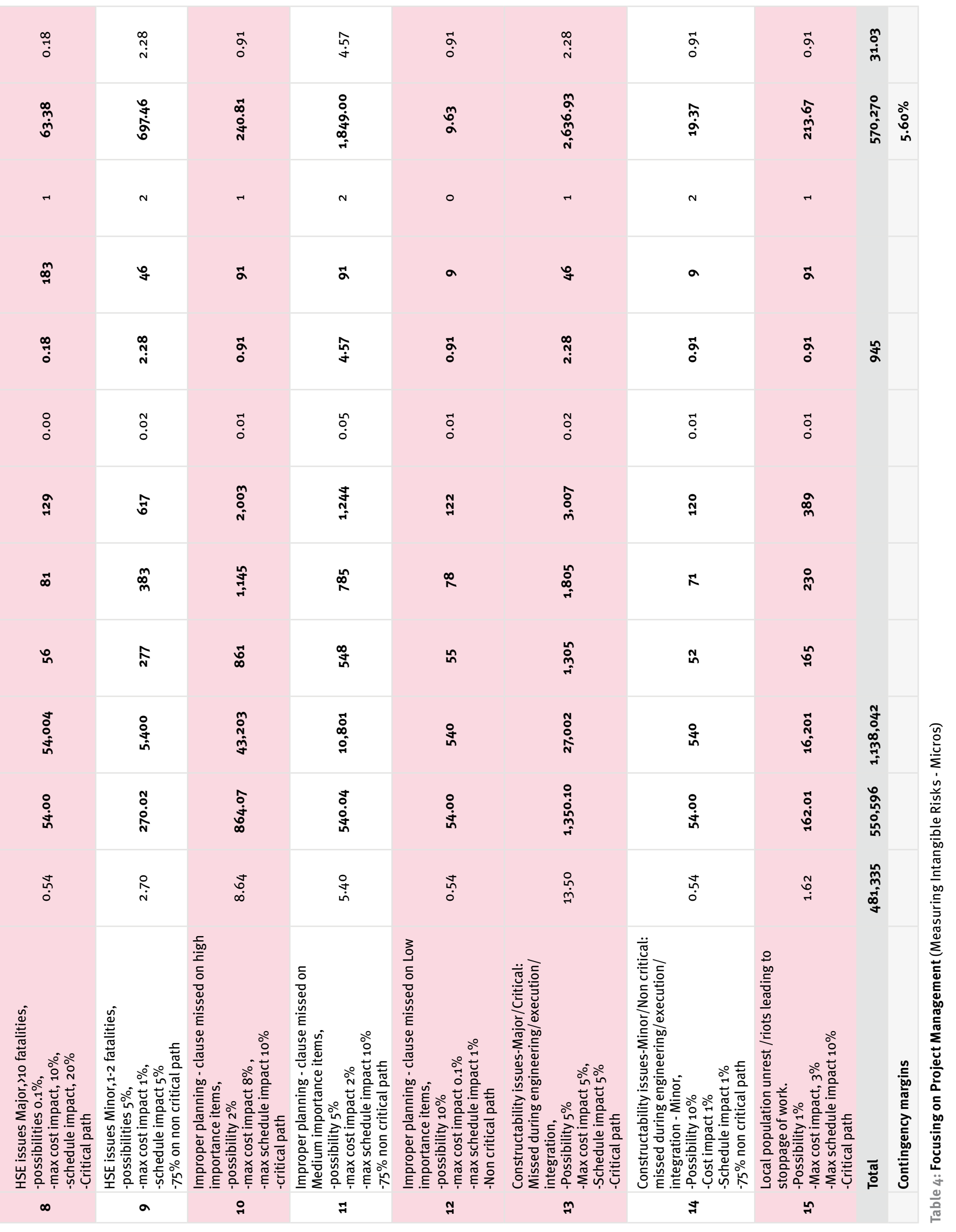




\section{Identify \& measure macro risks}

So far we have covered tangible and intangible risks, however, the impact of Macro economic factors such as Inflation rates and global economics and Forex positions remains untouched. These factors gain importance due to the very fact that usually, Bid is done at FEED stage, and it takes about a year before it goes to EPC bid process again, and thereafter by the time the project is awarded and execution starts, again almost a year is passed. While the vendor's usually offer their quotes with a limited validity period of 3-6 months. Hence projecting the actual cost of Project 1-2 years hence is inevitable using Macros. As the focus of current paper is more on project management related and bid process related Micros, hence only three macros considered primarily that would affect an EPC project - Local Inflation rates, Global Inflation rates for imported equipment and Forex rates variations. Sensing the impact of macro economic risk requires fixing a probable number in their variations. An estimate was prepared to foresee how these macro economic factors are likely to emerge during next two years based on past trends and expert analysis, which would affect the project values. This paper assumes following numbers for said Macros used for simulations, and summed up in Table 5.
It is further assumed that Macros shall be normally distributed as they correspond to free floating markets. Hence each Macro was assigned a mean and standard deviation metrics as shown above. Based on above the spread sheet was modified, and Monte Carlo simulations were run for key Project Parameters:

- Project Value

- Project overall schedule

- Hi cost item 1,2,3

- Lead Item 1, 2, 3 and their impact on Schedule. Mostly lead items are on critical path category 2 , as theirs orders are placed in advance with safe time periods for rest of the project to be executed and therefore although they are key in schedule determination, but may not be on critical path from project control point of view, unless unreasonable schedule escalation beyond $75 \%$ of the maximum delays expected.

Project values were projected by multiplying the Local and foreign contents with macros as following:

Local content projected-at-Macro = Local content, base * Local Inflation rates * Duration of project (assumed 1 year for simplicity)

Foreign content projected-at-Macro $=$ Foreign content, base * Foreign in- flation rates* Duration of Project (assumed 1 year, again)

It is further assumed in the analysis that

- $25 \%$ of the Project value shall be funded by FDI; hence $75 \%$ of the Local investment is required.

- $40 \%$ local contents are minimum requirement or Project targets.

- Of the $60 \%$ of foreign content $25 \%$ is funded by FDI directly, without having to go through the process of conversion, hence only $35 \%$ of the foreign procurements are met by local Forex purchases, where in Forex rates maters.

Monte Carlo simulations run again 1000 cases each time, and the Project values and schedule was projected again. Note that Macros have no impact on schedule. The results are displayed in Table 6 (for Costs) and Table 7 (for Schedule), which indicates the decision points for various bidding strategies.

\begin{tabular}{|c|c|c|c|c|}
\hline & Description & Min & Nor & Max \\
\hline 16 & $\begin{array}{l}\text { Inflation Local, } \% \\
\text { M ean, } 15 \% \text {, std dev } 5 \% \\
\text { (Applicable on Local content, assumed 40\%) }\end{array}$ & $10 \%$ & $15 \%$ & $20 \%$ \\
\hline 17 & $\begin{array}{l}\text { Inflation-global / economic boom, } \\
\text {-Mean } 7 \% \text {, std dev } 3 \% 243 \\
\text { (Applicable on all foreign content, assumed } 60 \% \text { ) }\end{array}$ & $4 \%$ & $7 \%$ & $10 \%$ \\
\hline 18 & $\begin{array}{l}\text { Forex rates IDR per USD, } \\
\text {-Mean, } 9000 \text {, STD deviation, } 800 \\
\text { (Applicable on all foreign content, assumed } 60 \% \text { ) } \\
\text { Assumed } 25 \% \text { of foreign expense met by FDI } \\
\text { remaining by Local Forex purchase. }\end{array}$ & $7,200.00$ & $9,000.00$ & 10,800 \\
\hline
\end{tabular}

Table 5: Macros Affecting Project Costs (Important due to 1-2 year lag in bid price and actual project execution timings) 


\begin{tabular}{|c|c|c|c|c|c|c|}
\hline & \multicolumn{3}{|c|}{$\begin{array}{l}\text { Costs (including all resources) } \\
\text { USD }{ }^{000}\end{array}$} & \multicolumn{3}{|c|}{ Monte Carlo Simulation Results } \\
\hline & Min & Nor & Max & $P_{50}$ & $P_{75}$ & $P_{90}$ \\
\hline $\begin{array}{l}\text { Project Value without any risk } \\
\text { considerations }\end{array}$ & 480,171 & 540,042 & 657,834 & 480,171 & 540,042 & 657,834 \\
\hline $\begin{array}{l}\text { Project Value with only tangible } \\
\text { Risk considerations }\end{array}$ & 480,171 & 540,042 & 657,834 & 559,866 & 570,073 & 578,579 \\
\hline$\%$, based on Normal & & $0 \%$ & & & & $7.14 \%$ \\
\hline $\begin{array}{l}\text { Project Value with tangible and } \\
\text { intangible Risks wetted }\end{array}$ & 480,171 & 540,042 & 657,834 & 571,213 & 581,254 & 591,577 \\
\hline$\%$, based on Normal & & $o \%$ & & & & $9.54 \%$ \\
\hline $\begin{array}{l}\text { Project Value with tangible, } \\
\text { intangible and Macro Risks } \\
\text { wetted }\end{array}$ & 480,171 & 540,042 & 657,834 & 629,004 & 644,769 & 657,013 \\
\hline$\%$, based on Normal & & $0 \%$ & & & & $21.66 \%$ \\
\hline Procurement Hi-cost 1 & 153,000 & 170,000 & 195,500 & 172,763 & 178,720 & 185,065 \\
\hline$\%$, based on Normal & & $0 \%$ & & & & $8.86 \%$ \\
\hline Procurement Hi-cost 2 & 117,000 & 130,000 & 156,000 & 134,742 & 140,338 & 146,012 \\
\hline$\%$, based on Normal & & $0 \%$ & & & & $12.32 \%$ \\
\hline Procurement Hi-cost 3 & 52,200 & 58,000 & 78,300 & 63,018 & 67,223 & 71,060 \\
\hline$\%$, based on Normal & & $0 \%$ & & & & $22.52 \%$ \\
\hline
\end{tabular}

\section{Table 6: Project Value Risk wetted (Decision Points)}

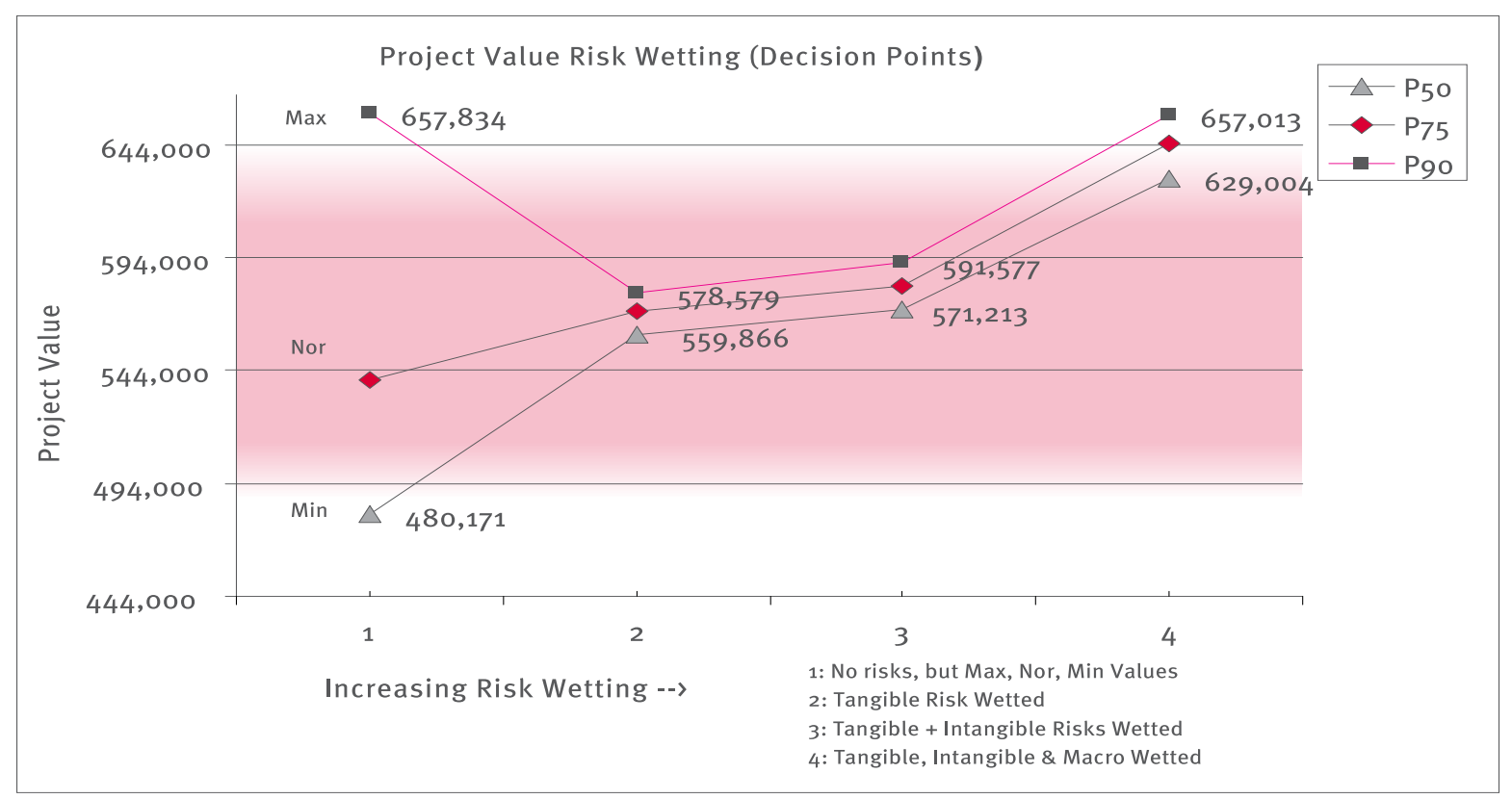

Figure 1: Project Value Risk wetting (Decision Points) 


\begin{tabular}{|c|c|c|c|c|c|c|}
\hline \multirow[b]{3}{*}{ Project Schedule without Risks } & \multicolumn{3}{|c|}{ Schedule, Days (including all risks) } & \multicolumn{3}{|c|}{ Monte Carlo Simulation Results } \\
\hline & Min & Nor & $\operatorname{Max}$ & \multirow[t]{2}{*}{$P_{50}$} & \multirow[t]{2}{*}{$P_{75}$} & \multirow[t]{2}{*}{$P_{90}$} \\
\hline & 820 & 947 & 1,041 & & & \\
\hline $\begin{array}{l}\text { Project Schedule with only } \\
\text { tangible Risk considered }\end{array}$ & 820 & 947 & 1,041 & 962 & 980 & 995 \\
\hline$\%$, based on Normal & \multicolumn{3}{|c|}{$0 \%$} & \multicolumn{3}{|r|}{$5.15 \%$} \\
\hline $\begin{array}{l}\text { Project Schedule with tangible } \\
\text { and intangible Risks wetted }\end{array}$ & 820 & 947 & 1,041 & 993 & 1,012 & 1,026 \\
\hline$\%$, based on Normal & \multicolumn{3}{|c|}{$0 \%$} & \multicolumn{3}{|r|}{$8.36 \%$} \\
\hline $\begin{array}{l}\text { Project Schedule with tangible, } \\
\text { intangible \& macro Risks wetted }\end{array}$ & 820 & 947 & 1,041 & 993 & 1,012 & 1,026 \\
\hline$\%$, based on Normal & & $o \%$ & & & & $8.36 \%$ \\
\hline Procurement Lead Item 1 & 252 & 280 & 308 & 280 & 289 & 295 \\
\hline$\%$, based on Normal & \multicolumn{3}{|c|}{$0 \%$} & \multicolumn{3}{|r|}{$5.26 \%$} \\
\hline Procurement Lead Item 2 & 207 & 230 & 253 & 229 & 236 & 242 \\
\hline$\%$, based on Normal & \multicolumn{3}{|c|}{$o \%$} & \multicolumn{3}{|r|}{$5.41 \%$} \\
\hline Procurement Lead Item 3 & 126 & 157 & 173 & 152 & 159 & 164 \\
\hline$\%$, based on Normal & \multicolumn{3}{|c|}{$\circ \%$} & \multicolumn{3}{|r|}{$4.54 \%$} \\
\hline $\begin{array}{l}\text { Impact of Lead Item } 1 \text { on } \\
\text { schedule }\end{array}$ & \multicolumn{3}{|c|}{$\begin{array}{l}75 \% \text { on Non critical path, exceeding which } \\
\text { becomes Critical }\end{array}$} & 49 & 57 & 63 \\
\hline $\begin{array}{l}\text { Impact of Lead Item } 2 \text { on } \\
\text { schedule }\end{array}$ & \multicolumn{3}{|c|}{$\begin{array}{l}75 \% \text { on Non critical path, exceeding which } \\
\text { becomes Critical }\end{array}$} & 40 & 48 & 54 \\
\hline $\begin{array}{l}\text { Impact of Lead Item } 3 \text { on } \\
\text { schedule }\end{array}$ & \multicolumn{3}{|c|}{$\begin{array}{l}75 \% \text { on Non critical path, exceeding which } \\
\text { becomes Critical }\end{array}$} & 22 & 29 & 34 \\
\hline
\end{tabular}

\section{Table 7: Project Schedule Risk wetted (Decision Points)}

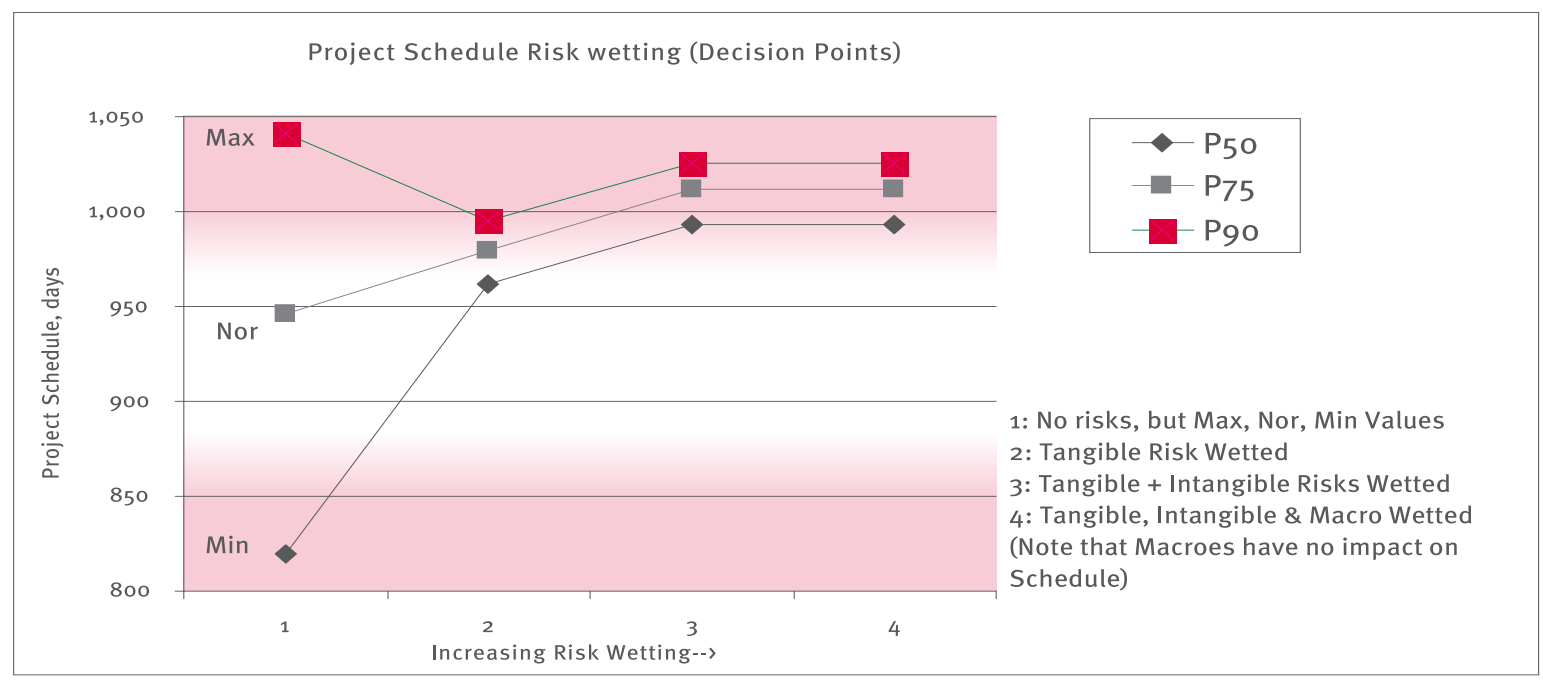

Figure 2: Project Schedule Risk Wetting (Decision Points) 


\section{Risk ranking}

After establishing the tangible and intangible risk estimates, we can see that Tangible risk estimates are in narrower range and close to the estimated numbers, hence more predictable. What make the greater difference are the intangible risks, therefore we shall establish a risk ranking on intangible risk only. Table 8 indicates the risk ranking derived after above analysis. The sorting is done primarily on P9o simulated values of risked values, then $\mathrm{P}_{75}$ and then $\mathrm{P}_{50}$ risk estimates.

Note that these ranking is not based on the absolute importance of the risk factors, instead the probabilistic estimates, which has two parts inherent: probability and Extent of risks. As such all of the above risk factors highly important concerns, but all of them can not be ranked number one. For example, HSE major concern with > 10 fatalities is ranked 11. At first glace it may look a bit awkward, however, knowing that these rankings are based on probabilistic estimates, very low probability items with high absolute risks go to lower rankings, while high probability items even with normal or lesser absolute damages get to higher ranking. Project risk management and Project control must consider the standard project procedures to maintain the probabilities and risk estimates within the range considered above. For example all the safety precaution should be well taken to maintain low probability of HSE factors, and their low ranking. The above risk ranking should not be misused to consider lesser safety precautions as the HSE risk ranking is low. This would violate the assumptions of risk ranking and HSE risk factor may become number one.

\section{Conclusions}

Retrospection of the methodology prescribed above would reflect that:

1. We have defined the risks

2. We micronized the big projects into small cost and schedule entities.

3. We have identified the tangible risks and their probabilistic estimates

4. We established tangible risk estimates running simulations and precipitated projected Project value and Schedule considering tangible risks

5. We have identified the intangible risk and learnt to characterize those using simple structuring principles applicable for EPC projects. Note that the numbers stated here are for illustration of the risk analysis. As such intangible risk measurement numbers are highly dependant on company strategies, consortium strengths, project size and location etc.

6. We established Intangible risk estimates running simulations and precipitated projected Project value and Schedule

\begin{tabular}{|c|c|c|c|c|}
\hline \multirow{2}{*}{$\begin{array}{l}\text { Intangible Risk Factors } \\
\text { Description }\end{array}$} & \multicolumn{4}{|c|}{ Monte Carlo Simulation Results } \\
\hline & P50 & P75 & P9o & $\begin{array}{c}\text { Risk } \\
\text { Ranking }\end{array}$ \\
\hline Sub contractor issues & 2,687 & 3,279 & 3,902 & 1 \\
\hline Constructability issues-Major/Critical: & 1,305 & 1,805 & 3,007 & 2 \\
\hline Non Availability of External Resources: & 845 & 1,164 & 2,029 & 3 \\
\hline Improper planning - clause missed on high importance items, & 861 & 1,145 & 2,003 & 4 \\
\hline Non Availability of Raw materials, MOC, other logistic issues & 842 & 1,128 & 1,980 & 5 \\
\hline Client's unsatisfied Major concerns & 681 & 965 & 1,590 & 6 \\
\hline Improper planning - clause missed on Medium importance items & 548 & 785 & 1,244 & 7 \\
\hline Re-work due to Poor Quality Engineering & 272 & 389 & 637 & 8 \\
\hline HSE issues Minor,1-2 fatalities & 277 & 383 & 617 & 9 \\
\hline Local population unrest / riots leading to stoppage of work & 165 & 230 & 389 & 10 \\
\hline HSE issues Major, >10 fatalities & 56 & 81 & 129 & 11 \\
\hline Improper planning - clause missed on Low importance items & 55 & 78 & 122 & 12 \\
\hline Constructability issues-Minor/Non critical: & 52 & 71 & 120 & 13 \\
\hline Client's Unsatisfied Minor concerns & 27 & 39 & 61 & 14 \\
\hline Unexpected Expediting Escalation & 2.53 & 3.41 & 5.57 & 15 \\
\hline
\end{tabular}

Table 8: Risk Ranking of Intangible Risk Factors 
considering Intangible risks.

7. We have established Macro risk estimations using normal distribution and running simulations

8. Identified $\mathrm{Hi}$ cost items and $\mathrm{Hi}$ lead items impact on critical path.

9. Established a risk ranking for Intangible Risk - Important for Project controls

10. Overall, we could develop a Risk Estimation model not only to estimate the tangible, intangible and Macro risks involved, but also to project a realistic and most probabilistic Project value and Schedule all Risks.

What is left is a discussion on risk sensitivity. In the above model, risk sensitivity can be considered based on their absolute impacts and not the differential measurements, as done traditionally. Differential measurements would not be applicable here as both cause and results are ranged already, any differential in the cause is already in the range. In case there is a possibility that the causing risk factor may go beyond the range estimated, then differential may be applied, but seems unrealistic as the range of variation goes along with the probabilities. For most pragmatic analysis, tangible risks are considering a random variation, while intangibles considering exponential variations. Hence Risk sensitivity has to be based on the absolute numbers, and therefore reflected in risk ranking itself.

It would be worthwhile to discuss a possible limitation of the above model. Note that both the tangible and intangible cost entities may already have an inherent effect of macros environmental changes. These risk estimates, if topped up again with macros will amount to double counting of the risks. Hence it is advisable to distinguish the two as much as possible or partially disregard the effect of Macro's in preparing bid estimates. An over counting of Risk estimates may result into an uncompetitive bid. The aim for Risk estimations is to secure a winning but profitable position for bidders and realistic schedule commitment to client.

Figure 1 indicates that an initial Maximum-Normal-Minimum range is rising upward, as more and more risks are considered. An initial Maximum estimate is almost equivalent to $P_{90}$ estimates of Tangible+ intangible +Macro risks together. See figure 1 for project values. While only tangible and intangible Risks are between Normal and maximum estimates.

Table 6 and 7 offers the Decision strategies for bidders. This is to be noted that a company's strategy to use this analysis may vary, subject to which risk they want to cover and to what extent. For example a company may decide to bid with $\mathrm{P}_{90}$ estimates of only Tangible and Intangible risks covered (\$591,577 in figure 1), excluding the effect of macros or assuming that it is already inbuilt in above two. Alternatively, a company may decide to use the $P_{50}$ value of 'All risk covered' i.e. \$ 629,004 in figure 1 . Hence there is several decision points made available as a result of this Risk analysis. It is advised to use the Risk analysis in view of consortium or company's strength and strategies, thereby optimizing the degree of risk. Accordingly the optimal decision point shown in figure 1 and 2 may vary for company to company and project to project, which depends on the most judicious decision of project managers, considering a holistic bid environment and timing and locations as well.

\section{References}

Asbjørn Rolstadås, Agnar Johansen, 2008 From Protective to Offensive Project Management, PMI Global Congress Proceedings - Marrakech, Morocco, 2008

David T. Hulett, 2004 'Using Quantitative Risk Analysis To Support Strategic Decisions' President, Hulett \& Associates, LLC, published Thomson GEE, London, UK, December 2004.

Kim Bang Salling, Risk Analysis and Monte Carlo Simulation within Transport Appraisal, Centre for Traffic and Transport, CTT-DTU, Build. 115, Technical University of Denmark.

Madhu Pillai, Dr Eric Sandelands, Ganesh Ashokan, 2010, Developing The EPC Value Chain In The Upstream Oil \& Gas Sector In Middle East, Oil \& Gas Business, 2010

Paté-Cornell, M. E., and Regan, P.J., 1998. Dynamic Risk Management Systems: Hybrid Architecture and Offshore Platform Illustration. Risk Analysis: An International Journal, 18(4), pp.485-496.

Sii, H.S., Wang, J., and Ruxton, T., 2003. A statistical review of the risk associated with offshore support vessel/platform encounters in UK waters. Journal of Risk Research, 6(2), pp.163-177.

S.M. Seyedhoseini1 and M.A. Hatefi, December 2009 Two-Pillar Risk Management (TPRM): A Generic Project Risk Management Process, Scientia Iranica, Vol. 16, No. 2, pp. $138\{148$ c Sharif University of Technology\} 